\title{
Clinicopathological correlation of invasive squamous cell carcinoma of uterine cervix: A cross-sectional study
}

\author{
Kalyani Raju ${ }^{1}{ }^{*}{ }^{,}$, Raghuveer CV ${ }^{1}$, Sheela SR ${ }^{2}$
}

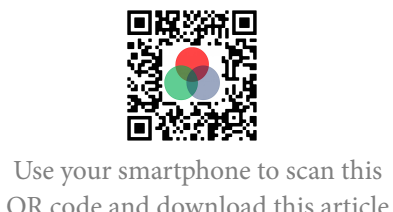

QR code and download this article

${ }^{1}$ Department of Pathology, Sri Devaraj Urs Medical College, Sri Devaraj Urs Academy of Higher Education and Research, Tamaka, Kolar, 563101, Karnataka, India

${ }^{2}$ Department of Obstretics \& Gynecology, Sri Devaraj Urs Medical College, Sri Devaraj Urs Academy of Higher Education and Research, Tamaka, Kolar, 563101, Karnataka, India

Correspondence

Kalyani Raju, Department of Pathology, Sri Devaraj Urs Medical College, Sri Devaraj Urs Academy of Higher

Education and Research, Tamaka, Kolar, 563101, Karnataka, India

Email: drkalyanir@rediffmail.com

\section{History}

- Received: Oct 05, 2019

- Accepted: Nov 20, 2019

- Published: Nov 26, 2019

DOI : 10.15419/bmrat.v6i11.573

\section{Check for updates}

\section{Copyright}

(c) Biomedpress. This is an openaccess article distributed under the terms of the Creative Commons Attribution 4.0 International license.

\begin{abstract}
Objective: Cervical cancer is a common cancer in females. Clinicopathological features vary and are heterogeneous in different studies. This study was taken up to know the clinicopathological correlation in squamous cell carcinoma (SCC) of the cervix in our population. Methods: This is a cross-section study. Histologically confirmed cases of squamous cell carcinoma of the cervix are considered. Clinical history, socio-demographic details, clinical findings including stage and histological grade of the disease are noted and statistically analyzed. Result: The age range of cases was $30-80$ years, with a mean of $54.2 \pm 12.0$. The age range at marriage was $12-23$ years, with a mean of $15.7 \pm 2.1$. Parity ranged from 1 to 11 , with a mean of $3.6 \pm 1.6$. The p-value between bleeding pervagina and other symptoms versus no bleeding per-vagina and other symptoms, stage of disease between pre \& peri-menopausal, and post-menopausal cases were 0.011 and 0.020, respectively. Growth followed by bleeding was common clinical findings. The $p$-value between the stage of the disease and age, histological grade and parity, histological grade and clinical features was 0.032 , 0.001 , and 0.031 respectively. Conclusion: Younger age group cases and pre \& peri-menopausal women present the disease at an early stage. Older age women present at an advanced stage. Higher parity had a higher risk of cervical cancer of well differentiated SCC. Bleeding per-vagina was a more common clinical presentation in post-menopausal women. Clinical features of bleeding per vagina with other symptoms were more common in well differentiated SCC.

Key words: cervical cancer, clinico-pathological features, squamous cell carcinoma, uterine cervix
\end{abstract}

\section{INTRODUCTION}

Cervical cancer is a major health problem and is leading cancer in women, especially in developing regions of the world, resulting in mortality and morbidity in their prime reproductive age. The age standardized rates estimated are 30 per 100,000 women. However, the incidence and mortality are decreased by 75 to $80 \%$ by a well programmed screening procedure in developed countries. Pap test for screening cervical cancer has tremendously decreased the incidence of cervical cancer. However, in developing countries, despite the existence of a screening procedure, the women present at the late stage of the disease with high mortality ${ }^{1-4}$.

The risk factors are early marriage, early age of first sexual intercourse, early age of first pregnancy, multiple pregnancies, increased parity, use of oral contraceptive pills, multiple sexual partners, low socioeconomic status with nutritional/vitamin deficiencies, poor genital hygiene especially penile hygiene of a male partner, rural women, African-American race, tobacco smoking, sexually transmitted disease, $\mathrm{Hu}$ man Papilloma virus infection, Herpes Simplex virus infection, co-infection with HIV, immune compromised status especially in renal transplanted cases and genetic susceptibility ${ }^{2-7}$. In addition, lack of awareness of screening programmes, geographical inaccessibility, lack of an oncologist, negligence of initial symptoms along with financial constraints is responsible for a late presentation and diagnosis ${ }^{7-9}$.

Clinicopathological studies are done and published in English literature. Clinicopathological features vary and are heterogeneous in different studies. Hence we have taken up this study to know the clinicopathological correlation in squamous cell carcinoma (SCC) of the cervix in our population.

\section{MATERIAL AND METHODS}

This is a cross sectional study done from October 2017 to September 2018. Ethical clearance for the study was obtained from the Institutional Ethical Committee. Clinically diagnosed and histopathologically confirmed 75 new cases of invasive SCC of the cervix were considered for the study. The exclusion criteria were Post-chemotherapy cases, post-radiotherapy cases, recurrence of the disease, cervical intraepithelial squamous neoplasia, glandular neoplasia, ade- 
nocarcinoma of the cervix, metastatic deposits (secondary deposits) in the cervix. Following informed consent from the patients, the socio-demographic profile including clinical presentation and physical examination findings as: age, hospital number, biopsy number, presenting complaints, menstrual history, personal history, past history, family history, perabdominal examination findings, per-speculum examination findings, per-vaginal examination findings and per-rectal examination findings were noted in a semi-structured proforma. The clinical stage and histological grade of the disease were also noted. The staging was done as per the FIGO staging system ${ }^{10}$. Histologically the cases were classified as keratinizing and non-keratinizing types ${ }^{11}$. Keratinizing squamous cell carcinomas were further classified as well differentiated (WDSCC), moderately differentiated (MDSCC), and poorly differentiated (PDSCC). The non-keratinizing squamous cell carcinomas were further classified as small cell type (NKSCSCC) and large cell type (NKLCSCC).

The data were entered in Microsoft Excel sheet. The data was analyzed using SPSS version 22 . The categorical data were recorded as frequency and proportions. Continuous data was entered as mean, standard deviation, and confidence intervals. Significance of difference between the groups was estimated using standard ' $\mathrm{t}$ ' test and chi-square test, $p$-value $<0.05$ was considered as statistically significant.

\begin{tabular}{|c|c|}
\hline Age range (years) & Cases \\
\hline $30-39$ & $8(10.6 \%)$ \\
\hline $40-49$ & $19(25.3 \%)$ \\
\hline $50-59$ & $18(24 \%)$ \\
\hline $60-69$ & $19(25.3 \%)$ \\
\hline $70-79$ & $10(13.3 \%)$ \\
\hline $80-89$ & $1(1.3 \%)$ \\
\hline Total & $75(100 \%)$ \\
\hline Total pre and peri-menopausal cases & $19(25.3 \%)$ \\
\hline Total post-menopausal cases & $56(74.7 \%)$ \\
\hline
\end{tabular}

\section{RESULTS}

The age distribution of the cases is shown in Table 1 . The age range was $30-80$ years of age, with a mean age of $54.2 \pm 12.0$. Maximum cases were seen in the age group of $40-49$ and $60-69$ years $(25.3 \%)$
Table 2: Shows the age in years at menopause among cases in the present study

\begin{tabular}{cc}
\hline Age in years at menopause & No of cases \\
Pre \& Peri-menopausal & $19(25.3 \%)$ \\
$40-44$ & $16(21.3 \%)$ \\
$45-49$ & $25(33.3 \%)$ \\
$50-54$ & $13(17.3 \%)$ \\
$55-59$ & $2(2.6 \%)$ \\
Total & $75(100 \%)$ \\
\hline
\end{tabular}

Table 3: Shows the age in years at marriage among cases in the present study

\begin{tabular}{cc}
\hline Age at marriage (years) & No of cases (\%) \\
12 & $5(6.6 \%)$ \\
13 & $2(2.6 \%)$ \\
14 & $12(16 \%)$ \\
15 & $20(26.6 \%)$ \\
17 & $11(14.6 \%)$ \\
18 & $10(13.3 \%)$ \\
19 & $11(14.6 \%)$ \\
20 & $1(1.3 \%)$ \\
22 & $1(1.3 \%)$ \\
23 & $1(1.3 \%)$ \\
Total & $1(1.3 \%)$ \\
\hline
\end{tabular}

Table 4: Shows the parity among cases in the present study

\begin{tabular}{cc}
\hline Para & No. of cases \\
Para 1 & $6(8 \%)$ \\
Para 2 & $11(14.6 \%)$ \\
Para 3 & $17(22.6 \%)$ \\
Para 4 & $20(26.6 \%)$ \\
Para $\geq 5$ & $21(28 \%)$ \\
Total & $75(100 \%)$ \\
\hline
\end{tabular}


followed by $50-59$ years (24\%). $74.7 \%$ of cases were postmenopausal, and $25.3 \%$ of cases were pre and peri-menopausal groups. Table 2 shows the age at menopause among the cases where the majority of females had attained menopause between 45-49 years (33.3\%) of age group followed by $40-44$ years $(21.3 \%)$. The age range was $40-57$ years, with a mean of $46.3 \pm 3.9$ years. Table 3 shows age at marriage among the cases where maximum cases were at 15 years $(26.6 \%)$ followed by 14 years $(16 \%)$ of age. The age range was $12-23$ years, with a mean of $15.7 \pm 2.1$ years of age. Table 4 shows the parity in cases where maximum cases had parity of $\geq 5$ (28\%) followed by $4(26.6 \%)$. Parity ranged from a $1-11$ with a mean of $3.6 \pm 1.6$.

Table 5 shows the varied clinical presentation in cases among pre \& peri-menopausal and post-menopausal women. The P-value between bleeding per-vagina and other symptoms versus no bleeding per-vagina and other symptoms between pre \& peri-menopausal and post-menopausal cases was 0.011 . In pre \& perimenopausal, women bleeding per-vagina and white discharge per vagina were approximately equally seen. Table 6 shows per-speculum findings of cases, among pre \& peri-menopausal and post-menopausal women. Growth followed by bleeding is the common findings in both pre \& peri-menopausal and post-menopausal women. The P-value for per-speculum findings between pre \& peri-menopausal and post-menopausal cases was 0.760 . Table 7 shows per-vaginal findings of cases, among pre \& peri-menopausal and post-menopausal women. The P-value of per-vaginal findings between pre \& peri-menopausal and postmenopausal cases was 0.347 .

Table 8 shows the stages of the disease in cases in both pre \& peri-menopausal and post-menopausal women. Maximum cases were seen in stage III (40\%). However, maximum cases in pre \& perimenopausal women were seen in stage II (36.8\%), and in post-menopausal women, it was seen in stage IV (48.2\%). The P-value of the stage of disease between pre $\&$ peri-menopausal and post-menopausal cases was 0.020 . Table 9 shows the histological grade of the disease in cases in both pre \& peri-menopausal and post-menopausal women. Keratinizing SCC was maximum, constituted $90.6 \%$ of cases, and nonkeratinizing 9.2\%. Among keratinizing SCC, maximum cases were WDSCC (56\%) followed by MDSCC (21.3\%). The P-value of grade of disease between pre $\&$ peri-menopausal and post-menopausal cases was 0.46 .

There was a statistically significant association between the stage of the disease and the age of the cases with a p-value of 0.032 . However, there was no statistically significant association between the stage of the disease with age at marriage $(\mathrm{p}=0.259)$, parity $(\mathrm{p}=0.752)$, clinical features $(\mathrm{p}=0.334)$ and perspeculum examination findings $(\mathrm{p}=0.295)$.

There was a statistically significant association between the histological grade of the disease with parity of the cases $(p<0.001)$ and clinical features of the disease $(p=0.031)$. However, there was no statistically significant association between histological grade and age of cases $(p=0.132)$, age at marriage $(p=0.578)$, and per-speculum examination findings $(\mathrm{p}=0.629)$.

\section{DISCUSSION}

Globally $13 \%$ of all deaths are due to cancer. Cervical cancer constitutes $5^{\text {th }}$ deadliest cancer worldwide, causing $5 \%$ of cancer death in females. It was leading cancer in women 50 years back and has decreased because of screening programmes which detect precancerous lesions and malignancy in the early stage ${ }^{8}$. Annually the incidence is approximately 510,000 cases, with 288,000 deaths worldwide. $80 \%$ of cases are recorded in developing countries. It occurs in 16 per 1000 women causing 9 per 1000 deaths in developing countries and accounts for 1.7 million cases. India accounts for $1 / 5^{\text {th }}$ of the world's cervical cancer cases, with 134,000 cases and 72,825 deaths ${ }^{5,9}$. In NICRH Dhaka, Bangladesh, $19.2 \%$ of women cancer constituted cervical cancer ${ }^{9}$. In a study at a tertiary health care center in South India, cervical cancer constituted $17 \%$ of female cancers ${ }^{3}$. Cervical cancer constituted $78.44 \%$ of all cancers of the female genital tract and $12.94 \%$ of all lesions of the cervix ${ }^{12}$.

Screening by Pap test has reduced the incidence and prevalence of cervical cancer. Screening every 5 and 3 years prevents cervical cancer by $84 \%$ and $91 \%$, respectively ${ }^{5}$. WHO predicts that by 2030 , approximately $98 \%$ of cervical cancer deaths will be reported from developing countries ${ }^{6}$.

Among the cervical cancer cases, Illiterates who can only sign were $50.7 \%$ and with primary education were $41.8 \%$. The percentage of women who were married, divorced, and widow was $74.6 \%, 3 \%$, and $19.4 \%$, respectively ${ }^{9}$. In a study, Jain DK et al., the illiterates were $97 \%$ and with primary education $3 \%{ }^{7}$. AmaroFilho SM et al., in their study, states that advanced stage (stage III \& IV) shows the significant statistical association $(\mathrm{p}<0.005)$ with no formal education ${ }^{14}$. In the present study illiterates were $90.6 \%$, and those with primary education were $10.4 \%$.

The mean age reported by Afroj et al. is $44.9 \pm 12.01$ years, with the age range of $20-75$ years ${ }^{9}$. In a study by Jain DK et al., the age range was $40-70$ years of age, 


\begin{tabular}{|c|c|c|c|}
\hline $\begin{array}{l}\text { Clinical } \\
\text { Presentation }\end{array}$ & $\begin{array}{c}\text { Total no of cases presented } \\
n=75(\%)\end{array}$ & $\begin{array}{l}\text { Pre \& Peri-menopausal cases } \\
n=19(\%)\end{array}$ & $\begin{array}{c}\text { Post-menopausal cases } \\
n=56(\%)\end{array}$ \\
\hline $\begin{array}{l}\text { Bleeding per } \\
\text { vagina }\end{array}$ & $60(80 \%)$ & $13(68.2 \%)$ & $47(83.9 \%)$ \\
\hline WDPV & $51(68 \%)$ & $10(52.6 \%)$ & $41(73.2 \%)$ \\
\hline Others & $48(64 \%)$ & $11(57.8 \%)$ & $37(66.0 \%)$ \\
\hline Pain Abdomen & $40(53.3 \%)$ & $12(63.1 \%)$ & $28(50.0 \%)$ \\
\hline $\begin{array}{l}\text { Post-coital } \\
\text { bleeding }\end{array}$ & $4(5.3 \%)$ & $1(5.2 \%)$ & $3(5.3 \%)$ \\
\hline Mass per vagina & $2(2.6 \%)$ & $1(5.2 \%)$ & $1(1.7 \%)$ \\
\hline No symptoms & $2(2.6 \%)$ & $2(10.5 \%)$ & - \\
\hline
\end{tabular}

WDPV: White discharge per vagina

\section{Table 6: Shows per-speculum findings of cases in the present study}

\begin{tabular}{lccc}
\hline Per-speculum findings & Total No. of cases & Pre \& Peri-menopausal cases & Post-menopausal cases \\
Growth & $49(65.3 \%)$ & $11(57.8 \%)$ & $38(67.8 \%)$ \\
Bleeding & $8(10.6 \%)$ & $2(10.5 \%)$ & $6(10.7 \%)$ \\
Erosion & $6(8 \%)$ & $3(15.7 \%)$ & $3(5.3 \%)$ \\
Ulcer & $5(6.6 \%)$ & $2(10.5 \%)$ & $3(5.3 \%)$ \\
Unhealthy & $3(4 \%)$ & $1(5.2 \%)$ & $2(3.5 \%)$ \\
Mass & $2(2.6 \%)$ & 00 & $2(3.5 \%)$ \\
Stenosis & $1(1.3 \%)$ & 00 & $1(1.7 \%)$ \\
WDPV & $1(1.3 \%)$ & 00 & $1(1.7 \%)$ \\
Total & $75(100 \%)$ & $19(100 \%)$ & $56(100 \%)$ \\
\hline
\end{tabular}

WDPV: White discharge per vagina

Table 7: Shows per-vaginal findings of cases in the present study

\begin{tabular}{lccc}
\hline Per vaginal examination & Total No. of cases & Pre \& Peri-menopausal cases & Post-menopausal cases \\
Friable Growth & $45(60.0 \%)$ & $11(57.8 \%)$ & $34(60.7 \%)$ \\
Induration & $28(37.3 \%)$ & $7(36.8 \%)$ & $21(37.5 \%)$ \\
Erosion & $1(1.3 \%)$ & 00 & $1(1.7 \%)$ \\
Stenosis & $1(1.3 \%)$ & $1(5.2 \%)$ & 00 \\
Total & $75(100 \%)$ & $19(100 \%)$ & $56(100 \%)$ \\
\hline Table 8: Shows stages of the disease in cases in the present study & \\
\hline Stage of the disease & Total No of cases & Pre \& Peri-menopausal cases & Post-menopausal cases \\
Stage I & $6(8 \%)$ & $4(21.0 \%)$ & $2(3.5 \%)$ \\
Stage II & $24(32 \%)$ & $7(36.8 \%)$ & $17(30.5 \%)$ \\
Stage III & $30(40 \%)$ & $3(15.7 \%)$ & $27(48.2 \%)$ \\
Stage IV & $15(20 \%)$ & $5(26.3 \%)$ & $10(17.8 \%)$ \\
Total & $75(100 \%)$ & $19(100 \%)$ & $56(100 \%)$ \\
\hline
\end{tabular}


Table 9: Shows histological grade of the disease in cases in the present study

\begin{tabular}{lccc}
\hline Grade of the disease & No of cases (\%) & Pre \& Peri-menopausal cases & Post-menopausal cases \\
WDSCC & $42(56 \%)$ & $13(68.4 \%)$ & $29(51.7 \%)$ \\
MDSCC & $16(21.3 \%)$ & $3(15.7 \%)$ & $13(23.2 \%)$ \\
PDSCC & $10(13.3 \%)$ & $1(5.2 \%)$ & $09(16.1 \%)$ \\
NKLCSCC & $5(6.6 \%)$ & $2(10.5 \%)$ & $3(5.3 \%)$ \\
NKSCSCC & $2(2.6 \%)$ & - & $2(3.5 \%)$ \\
Total & $75(100 \%)$ & $19(100 \%)$ & $56(100 \%)$ \\
\hline
\end{tabular}

WDSCC: Well differentiated squamous cell carcinoma MDSCC: Moderately differentiated squamouscell carcinoma PDSCC: Poorly differentiated squamous cell carcinoma NKLCSCC: Non-keratinizing large cell squamous cell carcinoma NKSCSCC: Non-keratinizing small cell squamous cell carcinoma

\section{Table 10: Shows the age distribution in various studies compared to the present study}

\begin{tabular}{ccccccc}
\hline $\begin{array}{c}\text { Age range } \\
\text { (years) }\end{array}$ & $\begin{array}{c}\text { Patil } \text { et al., } \\
\mathbf{2 0 1 9 ^ { 5 }}\end{array}$ & $\begin{array}{c}\text { Gundrajakuppan } \\
\text { et al., 2011 }\end{array}$ & $\begin{array}{c}\text { Sarwath } \text { et } \\
\text { al., 2017 }\end{array}$ & $\begin{array}{c}\text { Afroj } \text { et al., } \\
\mathbf{2 0 1 7 ^ { 9 }}\end{array}$ & $\begin{array}{c}\text { Gaikwad } \text { et } \\
\text { al., 2016 }\end{array}$ & $\begin{array}{c}\text { Present } \\
\text { study, 2019 }\end{array}$ \\
$20-29$ & $8.6 \%$ & $5.2 \%$ & $18.6 \%$ & $9 \%$ & $6.5 \%$ & - \\
$30-39$ & & & & $37.3 \%$ & $13.1 \%$ & $10.6 \%$ \\
$40-49$ & $65.3 \%$ & $60.5 \%$ & $51.4 \%$ & $26.9 \%$ & $27.6 \%$ & $25.3 \%$ \\
$50-59$ & & & & $20.9 \%$ & $32.8 \%$ & $24 \%$ \\
$60-69$ & $26 \%$ & $34.2 \%$ & $30.0 \%$ & $6 \%$ & $22.3 \%$ & $25.3 \%$ \\
$70-79$ & & & & - & & \\
$80-89$ & - & & - & - & & $13.3 \%$ \\
\hline
\end{tabular}

Table 11: Shows the parity in various studies compared with the present study

\begin{tabular}{|c|c|c|c|c|}
\hline Para & Patil et al., $2019^{5}$ & Afroj et al., $2017^{9}$ & Jain et al., $2017^{7}$ & Present study, 2019 \\
\hline Para 1 & $46 \%$ & $20.9 \%$ & $48 \%$ & $8 \%$ \\
\hline Para 2 & & & & $14.6 \%$ \\
\hline Para 3 & & & & $22.6 \%$ \\
\hline Para 4 & $53.9 \%$ & & & $26.6 \%$ \\
\hline Para $\geq 5$ & & $79.1 \%$ & $52 \%$ & $28 \%$ \\
\hline
\end{tabular}

with $87 \%$ of cases in more than 40 years of age and a mean age of 56.17 years $^{7}$. In a study by Esmeaili et al., the mean age of cervical cancer was 52 years with two peaks, one at 35-39 years and others at 6064 years of age ${ }^{4}$. In a study by Stoler et al., the mean age of cervical cancer was 41.0 years ${ }^{15}$.Advanced age is a risk factor. Postmenopausal bleeding is the most characteristic symptom in carcinoma cervix ${ }^{8}$. Hence cervical cancer should be suspected in cases of bleeding per vagina in old age ${ }^{12}$. Amaro-Filho SM et al., in their study, states that advanced stage (stage III \& IV) shows the significant statistical association $(p<0.005)$ with the advanced age of more than 55 years of age ${ }^{14}$. In the present study, the age range was 30 80 years of age, with a mean age of $54.2 \pm 12.0$. There was a statistically significant association between age and stage of the disease $(\mathrm{p}=0.032)$, indicating younger age group cases presented with early stage and older age group presented with a late stage of the disease. There was statistical significant association between the stage of disease versus pre $\&$ peri-menopausal and post-menopausal cases $(\mathrm{p}=0.020)$ indicating that pre \& peri-menopausal women present the disease in a relatively early stage compared to post-menopausal who present in late stage of the disease probably because of atrophied cervix and relatively less volume 
Table 12: Shows the clinical presentation in various studies compared with the present study

\begin{tabular}{|c|c|c|c|c|c|c|}
\hline $\begin{array}{l}\text { Clinical } \\
\text { Presentation }\end{array}$ & $\begin{array}{l}\text { Patil et al., } \\
2019^{5}\end{array}$ & $\begin{array}{c}\text { Gundrajakuppam } \\
\text { et al., } 2011^{8}\end{array}$ & $\begin{array}{l}\text { Afroj et } \\
\text { al., } 201^{9}\end{array}$ & $\begin{array}{l}\text { Gaikwad et } \\
\text { al., } 2016^{12}\end{array}$ & $\begin{array}{c}\text { Jain et al., } \\
2017^{7}\end{array}$ & $\begin{array}{c}\text { Present } \\
\text { study, } 2019\end{array}$ \\
\hline $\begin{array}{l}\text { Bleeding per } \\
\text { vagina }\end{array}$ & $53.3 \%$ & $21.0 \%$ & $80.5 \%$ & $69.7 \%$ & $65 \%$ & $80 \%$ \\
\hline $\begin{array}{l}\text { Post- } \\
\text { menopausal } \\
\text { bleeding }\end{array}$ & $16 \%$ & $28.9 \%$ & - & - & $65 \%$ & $85.7 \%$ \\
\hline WDPV & $64 \%$ & $44.7 \%$ & $67.1 \%$ & $39.4 \%$ & $72 \%$ & $68 \%$ \\
\hline Pain Abdomen & - & $0 \%$ & - & $19.7 \%$ & $28 \%$ & $53.3 \%$ \\
\hline $\begin{array}{l}\text { Post-coital } \\
\text { bleeding }\end{array}$ & $22.6 \%$ & - & $86.5 \%$ & $11.8 \%$ & - & $5.3 \%$ \\
\hline Mass per vagina & $0.6 \%$ & $2.6 \%$ & - & $3.9 \%$ & $13 \%$ & $2.6 \%$ \\
\hline Others & $66.6 \%$ & $2.6 \%$ & - & $14.4 \%$ & $83 \%$ & $64 \%$ \\
\hline No symptoms & - & $2.3 \%$ & - & - & - & $2.6 \%$ \\
\hline
\end{tabular}

WDPV: White discharge per vagina

\begin{tabular}{|c|c|c|c|}
\hline Per-speculum findings & Gundrajakuppam et al., $2011^{8}$ & Jain et al., $2017^{7}$ & Present study, 2019 \\
\hline Growth & $81.5 \%$ & $02 \%$ & $65.3 \%$ \\
\hline Bleeding & - & - & $10.6 \%$ \\
\hline Erosion & $5.2 \%$ & - & $8 \%$ \\
\hline Ulcer & $2.6 \%$ & $72 \%$ & $6.6 \%$ \\
\hline Unhealthy & - & - & $4 \%$ \\
\hline Mass & - & - & $2.6 \%$ \\
\hline Stenosis & - & - & $1.3 \%$ \\
\hline WDPV & - & - & $1.3 \%$ \\
\hline Others & $7.8 \%$ & $19 \%$ & - \\
\hline Normal & $2.6 \%$ & $07 \%$ & - \\
\hline
\end{tabular}

WDPV: White discharge per vagina

Table 14: Shows the stage of the disease in cases in various studies compared with the present study

\begin{tabular}{|c|c|c|c|c|c|}
\hline $\begin{array}{l}\text { Stage of the } \\
\text { disease }\end{array}$ & $\begin{array}{c}\text { Patil et al., } \\
2019^{5}\end{array}$ & $\begin{array}{c}\text { Afroj et al., } \\
2017^{9}\end{array}$ & $\begin{array}{c}\text { Jain et al., } \\
2017^{7}\end{array}$ & $\begin{array}{c}\text { Goellner, } \\
1976^{13}\end{array}$ & $\begin{array}{c}\text { Present study, } \\
2019\end{array}$ \\
\hline Stage I & $4.6 \%$ & $18.96 \%$ & - & $42.4 \%$ & $8 \%$ \\
\hline Stage II & $26.6 \%$ & $44.81 \%$ & $80 \%$ & $41.4 \%$ & $32 \%$ \\
\hline Stage III & $65.3 \%$ & $34.47 \%$ & $20 \%$ & $11.7 \%$ & $40 \%$ \\
\hline Stage IV & $33.3 \%$ & $1.72 \%$ & - & $4.6 \%$ & $20 \%$ \\
\hline
\end{tabular}


Table 15: Shows histological type of the disease in cases in various studies compared with the present study

\begin{tabular}{|c|c|c|c|c|}
\hline $\begin{array}{l}\text { Grade of the } \\
\text { disease }\end{array}$ & Patil et al., $2019^{5}$ & $\begin{array}{c}\text { Gaikwad et al., } \\
2016^{12}\end{array}$ & Jain et al., $2017^{7}$ & Present study, 2019 \\
\hline WDSCC & $22.2 \%$ & $11.84 \%$ & $62.7 \%$ & $56 \%$ \\
\hline MDSCC & $61.1 \%$ & $71.05 \%$ & $26.3 \%$ & $21.3 \%$ \\
\hline PDSCC & $16.6 \%$ & $17.11 \%$ & $1.8 \%$ & $13.3 \%$ \\
\hline NKLCSCC & - & - & $7 \%$ & $6.6 \%$ \\
\hline NKSCSCC & - & - & & $2.6 \%$ \\
\hline
\end{tabular}

WDSCC: Well differentiated squamous cell carcinoma

MDSCC: Moderately differentiated squamous cell carcinoma PDSCC: Poorly differentiated squamous cell carcinoma NKLCSCC: Non-keratinizing large cell squamous cell carcinoma NKSCSCC: Non-keratinizing small cell squamous cell carcinoma

of healthy cervical tissue resulting in fast spread of the disease. Hence younger patients and patients in the pre \& peri-menopausal age group presented at an early stage in the present study. There was no statistical association between age and histological grade of the disease in the present study. The age distribution in various studies compared to the present study is shown in Table 10, where maximum cases are seen between 40-59 years of age in all studies.

Early marriage is a risk factor as frank cases with late stage of the disease is noted when the age of marriage was between 15-19 years followed by 20-24 years ${ }^{8}$. Age at the marriage of fewer than 20 years was $49.25 \%$ of cases in a study by Afroj et al. ${ }^{9} 83 \%$ and $17 \%$ of cases had first coitus at less than or equal to 20 years and more than 20 years, respectively, in a study by Jain et al. ${ }^{7}$. Amaro-Filho SM et al., in their study, states that the advanced stage was also associated with the age of marriage at less than 17 years but not statistically significant $(\mathrm{p}=0.752)^{14}$. Cervical carcinoma behaves as a sexually transmitted disease ${ }^{8}$. There was no statistical association between age at marriage in cases with stage and histological grade of the disease in the present study. The age range for marriage was 12-23 years, with mean $15.7 \pm 2.1$ years of age. Maximum cases were between $15-18$ years (69.3\%), followed by $12-14$ years (25.3\%). Among cases between $15-18$ years, $59.6 \%$ of cases were in the advanced stage. Frank cervical cancer with the late stage was seen maximum with parity of $\geq 4$ followed by 3 in a study by Patil $\mathrm{N}$ et $a$ al. $^{5}$. Among cases, $3.8 \%$ were nulliparous, and $96.2 \%$ were multiparous in a study by Jyothi $\mathrm{V}$ et $a l^{6}$. Amaro-Filho SM et al., in their study, states that advanced stage (stage III \& IV) shows a significant statistical association $(\mathrm{p}<0.005)$ with more than four pregnancies ${ }^{14}$. In the present study, parity ranged from 1 to 11 , with a mean of $3.6 \pm 1$.6. There was no statistically significant association between parity and stage of the disease in the present study. However, $55 \%$ of para 4 cases and $66.6 \%$ of para $\geq 5$ were in an advanced stage (stage III \& IV). There was a statistically significant correlation between parity and histological grade of the disease $(\mathrm{p}=0.001)$ which indicates that higher parity had a higher risk of cervical cancer of WDSCC followed the MDSCC histological type. The parity in various studies compared with the present study is shown in Table 11, where maximum cases are seen with parity $\geq 4$ in all studies.

Patients of cervical cancer present with local and systemic symptoms. The local symptoms can be bleeding per vagina, mass per vagina, rarely leakage of urine, or feces per vagina. The systemic symptoms are loss of appetite, loss of weight, weakness, pelvic pain, pain in the leg, etc ${ }^{5}$. Irregular bleeding per vagina had a statistical association with stages of cancer $^{9}$. In the present study, there was a significant association between bleeding per-vagina and other symptoms versus no bleeding per-vagina and other symptoms between pre \& peri-menopausal and postmenopausal cases $(\mathrm{p}=0.011)$ which indicates that bleeding per-vagina was a more common clinical presentation in post-menopausal women than in pre \& peri-menopausal which can be due to atrophic cervix and age-related changes of blood vessels. There was also a statistical association between clinical presentation and histological grade of the disease $(\mathrm{p}=0.031)$ suggesting that the clinical features of bleeding per vagina with other symptoms were more common in WDSCC, followed by MDSCC than in cases without bleeding per vagina. In the present study, there was no statistical association between clinical presentation and stage of the disease. The clinical presentation in cases in various studies compared with the present study is shown in Table 12, where bleeding 
per-vagina is the most frequent presentation in the present study and study by Gaikwad et al ${ }^{12}$. WDPV was the most frequent presentation in a study by Patil et al., Gundrajakuppam et al., and Jain et al. ${ }^{5,7,8}$. Postcoital bleeding was the most frequent presentation in the study by Afroj et al. ${ }^{9}$.

The per-speculum findings in cases in various studies compared with the present study are shown in Table 13. The most frequent finding is growth, as reported by Gundrajakuppam et al. (81.5\%) and also in the present study $(65.3 \%)^{8}$. In a study by Jain et al. the most frequent finding was ulcer $(72 \%)^{7}$. The commonest per-vaginal examination findings reported is frank growth, which bleeds on touch ${ }^{8}$. Cervical growth was noted in $9.2 \%$ of cases in a study by Gaikwad SL et al. ${ }^{12}$. In the present study, growth which bleeds on touch was the commonest presentation. There was no statistical association between perspeculum findings with stage and histological grade of the disease.

Table 14 shows the stage of the disease in cases in various studies compared with the present study, where stage I was commonest in the study by Goellner ${ }^{13}$. Stage II was commonest in the study by Afroj et al. and Jain et al. ${ }^{7,9}$. Stage III was commonest in the study by Patil et al. and the present study ${ }^{5}$. Table 15 shows the histological type of the disease in cases in various studies compared with the present study where WDSCC is commonest in the present study and study by Jain et al. ${ }^{7}$. MDSCC was commonest in the study by Patil et al. and Gaikwad et al. ${ }^{5,12}$.

$44.44 \%$ of all the cervical biopsies were squamous cell carcinoma in a study by Jyothi $\mathrm{V}$ et al. ${ }^{6}$. Among cervical cancer, $80-90 \%$ of cervical cancer are squamous cell carcinoma and $14 \%$ adenocarcinoma, as reported by Patil $\mathrm{N}$ et al. ${ }^{5}$. Squamous cell carcinoma constituted $86.57 \%$ and adenocarcinoma $13.43 \%$ in a study by Afroj S et al. ${ }^{9}$. Squamous cell carcinoma constituted $95 \%$ of the cases of cervical carcinoma in a study Gaikwad SL et al. ${ }^{12} 91 \%$ of cases were squamous cell carcinoma, and $9 \%$ were adenocarcinoma in a study by Jain DK et al. Of squamous cell carcinoma, $91 \%$ were keratinizing type, $07 \%$ were non-keratinizing type, and $02 \%$ were basaloid type ${ }^{7}$. In a study by Sarwath et al., histological type analysis showed $26 \%$ were keratinizing and $68.8 \%$ non-keratinizing type ${ }^{1}$. In a study by Goellner et al., keratinizing was $29.0 \%$, and non- keratinizing was $71 \%{ }^{13}$. In the present study, the keratinizing and non-keratinizing types constituted $90.8 \%$ and $9.2 \%$, respectively.

There is no significant difference in the prognosis between histological types of tumors within any stage. However, large-cell cancers have a better prognosis than keratinizing cancers, and small-cell cancers have the worst prognosis. The stage of the disease has a definite impact on prognosis ${ }^{13}$. In the present study, the cases were not followed up for prognosis.

The limitation of the present study is that the cases were not followed up for prognosis. However a few objective conclusions were drawn by this study which can be generalized by doing a similar study in a larger population as; younger age group cases and pre \& peri-menopausal women present the disease at an early stage compared to post-menopausal women, older age presents with advanced stage, maximum cases were seen between 15-18 years of age of marriage, higher parity had a higher risk of cervical cancer of WDSCC and advanced stage, bleeding per-vagina was a more common clinical presentation in post-menopausal women than in pre \& perimenopausal, a growth which bleeds on touch was the common clinical examination findings in both pre \& peri-menopausal and post-menopausal, clinical features of bleeding per vagina with other symptoms were more common in WDSCC than cases without bleeding per vagina and other symptoms.

\section{CONCLUSION}

Cases with younger age present with early stages of cancer. Cervical cancer screening should be done in older age women more frequently, especially when the clinical feature is bleeding per vagina as they present with advanced stage. Young age at marriage and high parity are high risk factors for cervical cancer. WDSCC is associated with high parity and bleeding per vagina.

\section{ABBREVIATIONS}

FIGO: International Federation of Gynecology and Obstetrics

HIV: Human Immunodeficiency Virus

MDSCC: Moderately differentiated squamouscell carcinoma

NKLCSCC: Non-Keratinizing Large Cell squamous cellcarcinoma

NKSCSCC: Non-Keratinizing Small Cell squamous cellcarcinoma

PDSCC: Poorly differentiated squamous cell carcinoma

SCC: squamous cell carcinoma

WHO: World Health Organisation

WDPV: White discharge per vagina

WDSCC: Well differentiated squamous cell carcinoma 


\section{COMPETING INTERESTS}

We have no conflict of interest to declare.

\section{AUTHORS' CONTRIBUTIONS}

Kalyani Raju: Concept, collection of data, review of literature, case collection, statistical analysis, drafting / editing / review of manuscript. Raghuveer CV: Concept, editing / review of manuscript. Sheela SR: Case collection, editing manuscript.

\section{ACKNOWLEDGEMENTS}

We acknowledge Dr Sunil Bhage, Assisstant Professor of Comminity Medicine, Sri Devaraj Urs Medical College, Sri Devaraj Urs Academy of Higher Education and Research, Kolar. Karnataka, for contribution in statistical analysis.

\section{REFERENCES}

1. Sarwath $H$, Bansal D, Husain NE, Mohamed M, Sultan AA, Bedri S. Introduction of p16INK4a as a surrogate biomarker for HPV in women with invasive cervical cancer in Sudan. Infect Agent Cancer. 2017;12(1):50. PMID: 29021820. Available from: 10. 1186/s13027-017-0159-0.

2. Ahmed SA, Obaseki DE, Mayun AA, Mohammed A, Rafindadi $\mathrm{AH}, \mathrm{Abdul} \mathrm{MA}$. The role of biomarkers (p16INK4a and Ki-67) in cervical cancer screening: an appraisal. Ann Trop Pathol. 2017;8(1):1-4. Available from: 10.4103/atp.atp_3_17.

3. Kalyani R, Das S, Bindra MSS, Kumar HM. Cancer profile in Kolar: A ten years study. Indian J Cancer. 2010;47(2):160-5. PMID: 20448380. Available from: 10.4103/0019-509X.63011.

4. Esmaeili HA, Pourlak T, Ghamari B, Shayan FK, Sanaat Z, Soltani $\mathrm{GG}$, et al. Comparison of nuclear P16 immunostaining in atypical and normal endocervical glands: A descriptive analytical study. J Anal Res Clin Med. 2018;6(2):66-71. Available from: 10.15171/jarcm.2018.010.
5. Patil N, Deshmukh V, Rathid A, Jyoti D, Chavan S. Clinicopathological Correlation of Cervical Carcinoma: A Tertiary Hospitalbased Study. Int J Sci Stud. 2019;6(10):1-4.

6. Jyothi V, Manoja V, Reddy SK. A Clinicopathological Study on Cervix. Journal of Evolution of Medical and Dental Sciences. 2015;4(13):2100-6.

7. Jain DK, Shukla P, Gupta V. Clinicopathological Survey of Carcinoma Uterine Cervix In Patients Attending Tertiary Care Hospital Of Central Uttar Pradesh. Int J Sci Res (Ahmedabad). 2017;6(9):63-5.

8. Gundrajakuppam L, Vissa S, Nandam MR, Sreesailam S, Majety DV, Kuppali VM, et al.; 2011.

9. Afroj S, Banu MA, Sultana S, Jahan R, Rahman S, Begum N. Clinicopathological Profile of Cervical Cancer patients attending in a specialized Hospital. J Dhaka Med Coll. 2017;26(2):11721. Available from: $10.3329 /$ jdmc.v26i2.38826.

10. Pecorelli S, Zigliani L, Odicino F. Revised FIGO staging for carcinoma of the cervix. Int J Gynaecol Obstet. 2009;105(2):107-8. PMID: 19342051. Available from: 10.1016/j.ijgo.2009.02.009.

11. Stoler M, Bergeron C, Colgan TJ, Ferenczy AS, Herrington CS, Kim KR, et al.. Kurman RJ, Carcangin ML, Herrington CS, Young $\mathrm{RH}$, editors. Squamous cell tumors and precursors. Lyon: International Agency for Research on Cancer; 2014.

12. Gaikwad SL, Valand AG, Agarwal NU. Clinicohistopathological analysis of lesions of uterine cervix in Ambejogai city of Maharashtra: A 2 year study at tertiary level hospital. Journal of Diagnostic Pathology and Oncology. 2016;1(2):32-5.

13. Goellner JR. Carcinoma of the cervix. Clinicopathologic correlation of 196 cases. Am J Clin Pathol. 1976;66(5):775-85. PMID: 983986. Available from: 10.1093/ajcp/66.5.775.

14. Amaro-Filho SM, Golub JE, Nuovo GJ, Cunha CB, Levi JE, Villa $\mathrm{LL}$, et al. A comparative analysis of clinical and molecular factors with the stage of cervical cancer in a Brazilian cohort. PLoS One. 2013;8(3):e57810. PMID: 23505442. Available from: 10.1371/journal.pone.0057810.

15. Stoler MH, Wright TC, Ferenczy A, Ranger-Moore J, Fang Q, Kapadia $\mathrm{M}$, et al. Routine Use of Adjunctive p16 Immunohistochemistry Improves Diagnostic Agreement of Cervical Biopsy Interpretation: Results From the CERTAIN Study. Am J Surg Pathol. 2018;42(8):1001-9. PMID: 29697437. Available from: 10.1097/PAS.0000000000001072. 